\title{
Bilateral variation in origin of facial artery in a cadaver
}

\author{
Kumal JPP', Timsina RP², Yadav SK ${ }^{3}$, Gogoi P4
}

'Jay Prakash Prasad Kumal; ${ }^{2}$ Ram Prasad Timsina; ${ }^{3}$ Sanjay Kumar Yadav, Lecturers; ${ }^{4}$ Paramananda Gogoi, Professor; Department of Anatomy, Kathmandu Medical College Teaching Hospital, Duwakot, Bhaktapur, Nepal

\begin{abstract}
Anatomical knowledge of the origin, course, and branching pattern of the facial artery is important for surgeons and radiologist. However abnormal pattern of facial artery may change the result of the treatment, if it is not predicted in advance. Here we report bilateral variation in origin of facial artery originated as a linguo-facial trunk from external carotid artery.
\end{abstract}

Key words: facial artery, lingual artery, linguo-facial trunk, external carotid artery.

\section{INTRODUCTION}

$\mathrm{F}$ acial artery arises anteriorly from the external carotid artery in the carotid triangle, above the lingual artery and immediately above the greater cornu of hyoid bone. Facial artery passes from the carotid to digastric triangle deep to posterior belly of digastric. Medial to mandibular ramus it arches upwards and grooves the posterior aspect of the submandibular gland. It then winds round the base of mandible to enter the face at anteroinferior border of masseter muscle. Branches of facial artery in neck are ascending palatine, tonsilar artery, submental artery and glandular branches.

In the face, it may pass over or through levator labii superioris, and pursues a tortuous course along the side of the nose towards the medial corner of the eye. At its termination it is embedded in levator labii superior alaequae nasi. Branches of the facial artery in the face include premasseteric artery- to supply adjacent tissues and masseter muscle, inferior labial artery- to the lower lip, superior labial artery- to the upper lip and septum of nose, lateral nasal artery- to the ala and dorsum of the nose'.

The knowledge of existence of variations in branching patterns as well as termination of facial artery will help the surgeons to avoid complications during facial

Address for correspondence

Jay Prakash Prasad Kumal

Lecturer

Department of Anatomy

Kathmandu Medical College Teaching Hospital, Duwakot,

Bhaktapur, Nepal

E-mail:jppkumal@gmail.com reconstructive and other surgical procedures on face. In head and neck cancer facial artery is often selected as target artery for administration of super selective intra-arterial chemotherapy by inserting catheter from superficial temporal artery ${ }^{2}$. Variation in the origin of facial artery and its glandular branches are important in parotid surgeries and submandibular sialoadenectomy respectively.

In this paper, we report bilateral variation in origin of facial artery in an adult male cadaver, arising as a common trunk with the lingual artery as linguo-facial trunk.

\section{CASE REPORT}

The bilateral variation in origin of facial artery from external carotid was observed in an adult male cadaver during routine dissection classes for undergraduate medical students in Department of Anatomy, Kathmandu Medical College Teaching Hospital, Duwakot, Bhaktapur.

The facial and lingual arteries were arising anteriorly from the external carotid as a common linguo-facial trunk above the greater cornu of the hyoid bone. The trunk was separated by posterior belly of digastric muscle and hypoglossal nerve (shown in figure 1 and 2). Branches of facial and lingual artery were found normal. Premesseteric artery was observed near the anterior border of masseter muscle supplying the adjacent tissue. The venous drainage of the face was found normal on both sides. 


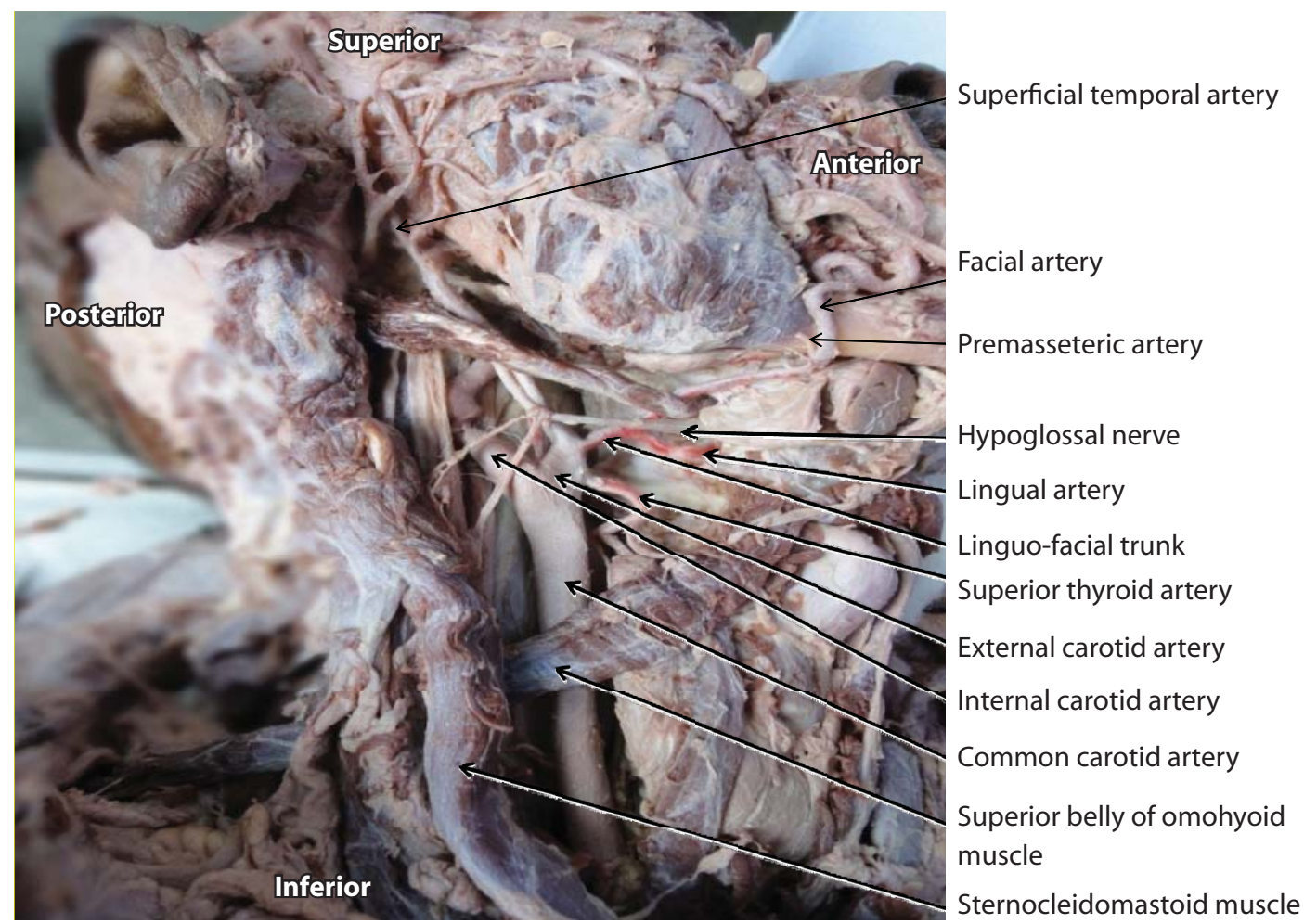

Figure 1: Variation in origin of facial artery (Right side)

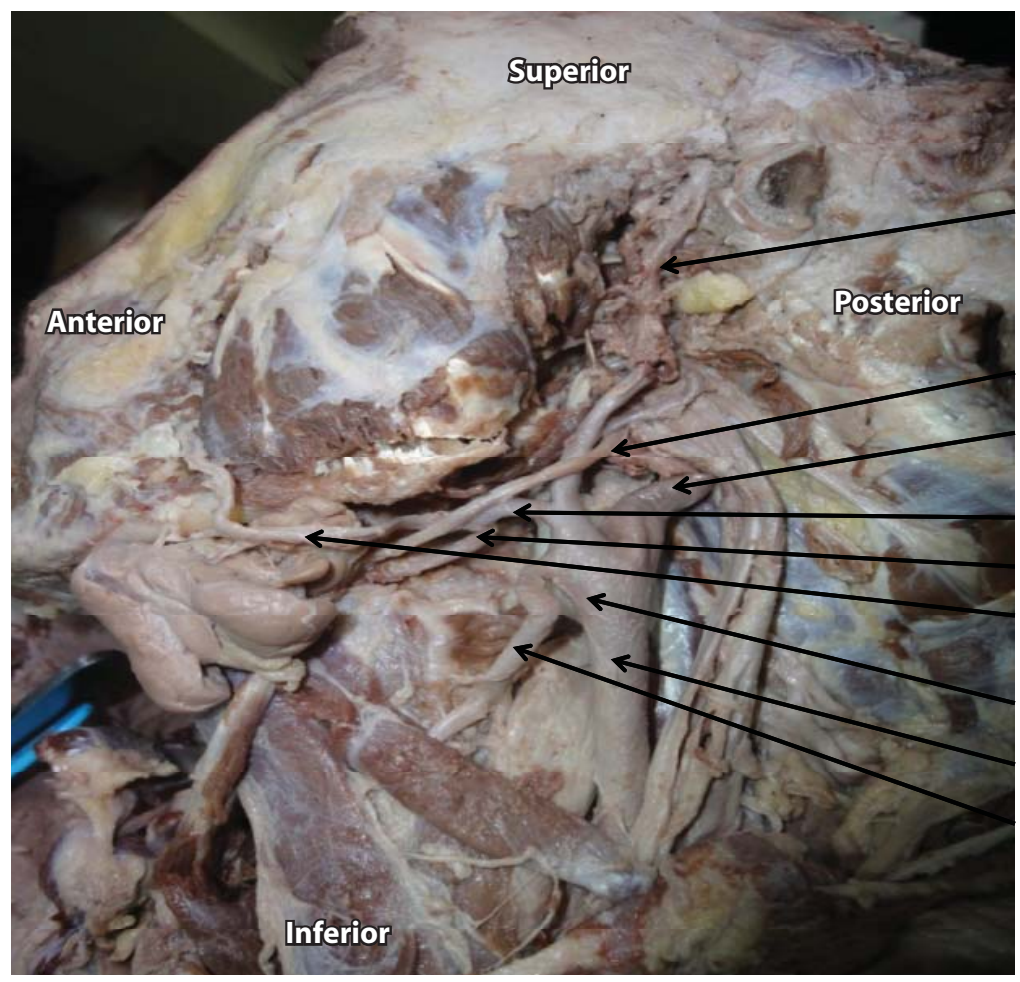

Superficial temporal artery

Hypoglossal nerve

Internal carotid artery

Linguo-facial trunk

Lingual artery

Facial artery

External carotid artery

Common carotid artery

Superior thyroid artery

Figure 2: Variation in origin of facial artery (Left side)

\section{DISCUSSION}

The location of the common carotid bifurcation, the branching pattern of the external carotid artery and the variations in its originated branch are known quite well. These branches can originate from a common trunk. Facial artery may show variations in its origin, course, 
termination and branching pattern. It may be totally absent and in such case, the transverse facial artery, ophthalmic artery and maxillary artery will supply its territory ${ }^{3,4}$. Ezure et $\mathrm{al}^{2}$ reported the complete absence of facial artery. There are different patterns of origin of superior thyroid, lingual and facial arteries. Facial artery may take origin along with the lingual artery as linguofacial trunk $k^{5}$ or with the maxillary artery as maxillofacial trunk ${ }^{6}$. In its course the artery may fail to loop around the Submandibular salivary gland ${ }^{7}$. Ozgur et $\mathrm{al}^{8}$ (2008) classified the origins of these arteries into four type which originated from the external carotid artery and reported their incidences. The separate origins of the arteries were marked as type 1 ( $90 \%$ cases); the linguofacial trunk as type 2 (7.5\%); the thyrolingual trunk as type $3(2.5 \%)$; and thyrolinguofacial trunk as type 4 .

Yildirim et $\mathrm{al}^{9}(2001)$, observed a total of six (15\%) linguofacial trunks in 20 adult human cadaver on both sides of the neck. Troupis et al ${ }^{10}$ performed dissections on 15 cadavers and found only one common linguo-facial trunk. Bergman et $\mathrm{al}^{5}$ reported the linguo-facial trunk in $10-20 \%$ of cases. Zumre et al ${ }^{11}$ reported linguo-facial trunk in $20 \%$ of cases, thyrolingual trunk in $2.5 \%$ and thyrolinguofacial trunk in $2.5 \%$ of the human foetuses.

\section{REFERENCES}

1. Standring S. Gray's Anatomy: The Anatomical Basis of Clinical Practice. 40th ed. London: Churchill Livingstone Elsevier;c2008. Chapter 28, Neck; p.4447.

2. Ezure H, Mori R, Ito J, Otsuka N. Case of a completely absent facial artery. Int J Anat Var. 2011;4:72-4.

3. Tubbs RS, Salter EG, Oakes WJ. Unilateral agenesis of the facial artery with compensation by a giant transverse facial artery. Folia Morphol. 2005 Aug;64:226-8.

4. Blair CB, Nandy K, Bourne GH. Vascular anomalies of the face and neck. Anat Rec. 1962 Nov1;144(3):2517.

5. Bergman RA, Afifi AK, Miyauchi R. Compendium of Human Anatomical Variations: Catalog, Atlas and World Literature. Urban \& Schwarzenberg, Baltimore and Munich. 1988;65.

6. Pretterklieber ML, Krammer EB, Mayr R. A Bilateral Maxillofacial Trunk in Man:An Extraordinary Anomaly of the Carotid System of Arteries. Cells Tissues Organs. 1991;141(3):206-11.
In the present case, facial artery was arising from a linguo-facial trunk (type-2) bilaterally crossed by hypoglossal nerve. Marx et $\mathrm{al}^{7}$ reported the bilateral variation in origin of facial artery. Nayak ${ }^{12}$ has reported the origin of the facial artery in the parotid gland and Mohandas ${ }^{13}$ encountered a case of high origin of facial artery along with variant origin of the glandular branch for submandibular gland from external carotid artery.

Variation in the origin and in its branches of the facial artery bilaterally are rare findings and impart important knowledge that is especially useful for surgeons who operate on the face and neck regions as well as for radiologists in the interpretation of images.

\section{CONCLUSION}

This case presents a variation in origin of facial artery on both sides derived from a linguo-facial trunk. Variations concerning the origin and branch of facial artery should be kept in mind to avoid complications during various surgical procedures for surgeon and also for radiologist while evaluating radiographs. These variations in branching of external carotid artery are of paramount importance not only in clinical practice but also in theoretical considerations.

7. Marx C, Kumar P, Reddy S, Vollala VR. Bilateral variation of facial artery: a case report. Rom J Morphol Embryol. 2008;49:399-401.

8. Ozgur Z, Govsa F, Ozgur T. Assessment of origin characteristics of the front branches of the external carotid artery. J Craniofac Surg. 2008;19(4):1159-66.

9. Yildirim M, Tanyeli E, Soyluoglu Al, Tuna Y. Truncus linguofacialis sikling. Morfoloji Der. 2001;9(1):33-4.

10. Troupis TG, Dimitroulis D, Paraschos A, Michalinos A, Protogerou V, Vlasis $K$, et al. Lingual and facial arteries arising from the external carotid artery in a common trunk. Am Surg. 2011Feb;77(2):151-4.

11. Zumre O, Salbacak A, Cicekcibasi AE, Tuncer I, Seker $M$. Investigation of the bifurcation level of the common carotid artery \& variations of the branches of the external carotid artery in human fetuses. Ann Anat. 2005;187(4):361-9.

12. Nayak S. Abnormal intra-parotid origin of the facial artery. Saudi Med J. 2006 oct;27(10):1602.

13. Mohandas Rao KG. Unilateral high origin of facial artery associated with a variant origin of the glandular branch to the submandibular gland. Int J Anat Var. 2009;2:136-7. 